\title{
Mechanism of Compact-colony Formation by Strains of Staphylococcus aureus in Serum Soft Agar
}

\author{
By KOSAKU YOSHIDA, TOSHICHIKA OHTOMO \\ AND YOSHIHISA MINEGISHI \\ Department of Microbiology, St Marianna University School of Medicine, \\ 2095, Sugao, Takatu-ku, Kawasaki 213, Japan \\ (Received 24 February 1976; revised 7 June 1976)
}

\begin{abstract}
SUMMARY
Compact-colony forming active substance (CCFAS), the material responsible for the compact colonies of Staphylococcus aureus observed in serum soft agar, was found to be an alkaline-stable, associated polysaccharide containing galactose, $\mathrm{N}$-acetylglucosamine, ribitol, phosphorus and a small quantity of alanine. This substance, when extracted from strains unable to produce protein A and clumping factor, was able to absorb the serum-reacting factor whereas a teichoic acid preparation of one strain could not. The formation of CCFAS was unaffected by the age of the cells, whereas when staphylococci were cultured at alkaline $\mathrm{pH}$, young cells produced more clumping factor than old ones. Both fibrinogen and its degradation products were capable of inducing compact colonies in a strain of $S$. aureus. The ability of human sera to interact in compact-colony formation was independent of the immunoglobulin content. Thus neither protein A, clumping factor, nor teichoic acid participate in the CCFAS reaction.
\end{abstract}

\section{INTRODUCTION}

The colonial forms of Staphylococcus aureus grown in serum soft agar (SSA) have been typed as diffuse (encapsulated) and compact (nonencapsulated). Finkelstein \& Sulkin (I958) and Iwata \& Eda (I968) suggested that compact-colony formation of $S$. aureus strains in this medium involved an antigen-antibody reaction between cells and serum. Although Alami \& Kelly (I959) had shown compact colonies in fibrinogen soft agar, Forsum, Forsgren \& Hjelm (1972) proposed that protein A of the cells that reacted with the Fc fragment of IgG in serum was responsible. Yoshida (I973) observed a change in colonial morphology from compact to the diffuse type in SSA when the $\mathrm{pH}$ was altered from alkaline to acid. This result suggests that protein A was not responsible for the phenomenon.

Yoshida, Ohtomo \& Minegishi (I975) extracted a cell-surface associated polysaccharide which absorbed the reacting factor in human sera and tentatively designated it as the compact-colony forming active substance (CCFAS). This paper describes the biochemical properties of the CCFAS and the reacting substance in human serum.

\section{METHODS}

Strains. The three strains used were PS 84 (phage-propagating standard strain), 32 (isolated from a human source) and wood 46 . All produced coagulase and deoxyribonuclease, fermented mannitol, released acid phosphatase (Yoshida, Smith \& Naito, 1970), and showed compact-type growth in SSA. Strains PS84 and wood 46 were both clumping factor positive but strain 32 was negative. Strain wood 46 was protein A negative. 
Media and cultural conditions. Brain-heart infusion (BHI, Difco) was used in SSA or fibrinogen soft agar. The medium used for the production of CCFAS was composed of 900 $\mathrm{ml} \mathrm{BHI}$ dialysate and $100 \mathrm{ml} 0 \cdot 03 \mathrm{M}-\mathrm{Tris} / \mathrm{HCl}, \mathrm{pH} \mathrm{8} \cdot 4$.

The serum soft agar technique was that of Finkelstein \& Sulkin (1958). The fibrinogen soft agar method was performed according to Alami \& Kelly (1959) using fibrinogen (AB KABI, Stockholm, Sweden). After incubation at $37^{\circ} \mathrm{C}$ for $24 \mathrm{~h}$, colonial morphologies of the organisms were determined. One unit of serum activity (Yoshida, I973) was $0.1 \mathrm{ml}$ of the maximum dilution of pooled human sera producing distinct compact type growth (without tailing) in SSA. These sera were used throughout the experiments involving soft agar.

Production and purification of CCFAS. Crude CCFAS was prepared as previously described (Yoshida et al., I975). Crude CCFAS (500 mg) was dissolved in $\mathrm{I} \cdot 0 \mathrm{ml} 0.03 \mathrm{M}$-Tris/ $\mathrm{HCl}$ buffer, $\mathrm{pH} 8.4$ (Tris buffer) and applied to a DEAE-cellulose column $(3.0 \mathrm{~cm}$ i.d. $\times$ I 20 $\mathrm{cm}$ ) which had been equilibrated with this buffer. Fractionation was performed using 21 Tris buffer with a linear sodium chloride gradient from zero to $0.4 \mathrm{M}$. The series of fractions giving the first peak in absorbance at $260 \mathrm{~nm}$ was concentrated by lyophilization. A portion $(300 \mathrm{mg}$ ) of this substance was dissolved in $\mathrm{I} \cdot 0 \mathrm{ml}$ Tris buffer and dialysed against the buffer at $4^{\circ} \mathrm{C}$ overnight. This solution was applied to a Sephadex G-200 column $(3.0 \mathrm{~cm}$ i.d. $\times 80$ $\mathrm{cm})$, which had been equilibrated with the buffer, and was eluted with the Tris buffer.

Chemical composition of CCFAS. Total sugar, hexosamine and $N$-acetylglucosamine contents of CCFAS were determined by the methods of Morris (I948), Elson \& Morgan (I953) and Spiro (1959), respectively. Ribitol content was measured using a gas chromatograph (type GC-4B; Shimadzu, Kyoto, Japan). Phosphorus content was determined by the method of Matuno \& Slade (I970). The CCFAS was hydrolysed with $6 \mathrm{M}-\mathrm{HCl}$ at $105^{\circ} \mathrm{C}$ for $\mathrm{I} 2 \mathrm{~h}$ before chemical analysis. The $\mathrm{HCl}$ was removed from the hydrolysate by repeated evaporation in a desiccator over solid sodium hydroxide. The sugar released from the CCFAS was analysed by thin-layer chromatography (t.1.c.) on $10 \times 10 \mathrm{~cm}$ cellulose glass plates using two different solvent systems: A, n-propanol/water/30\% $\mathrm{NH}_{4} \mathrm{OH}$ (2I:9: I, by vol.); $\mathrm{B}, \mathrm{n}$-butanol/pyridine/water $(6: 4: 3$, by vol.). Plates were stained with Tollens' silver nitrate reagent by the method of Trevelyan, Procter \& Harrison (1950).

Heat and pH stability. CCFAS in Tris buffer was heated at $80^{\circ} \mathrm{C}$ and at $105^{\circ} \mathrm{C}$ for 30 $\min$. The heat treatment was repeated in phosphate buffers at $\mathrm{pH} 7 \cdot 0$ and $6 \cdot 0$. The ability of heated samples to absorb the serum reacting factor was examined (see below).

\section{Role of serum factors}

Absorption of serum reacting factor by various cellular products. The titre of CCFAS activity was determined by doubling serial dilutions of pooled normal rabbit sera in sterile Tris buffer. A BHI culture in the exponential phase of growth was diluted $1: 10^{6}$, and mixtures of $0.1 \mathrm{ml}$ diluted suspension and $\mathrm{Io} \mathrm{ml} \mathrm{BHI}$ containing $0.15 \%(\mathrm{w} / \mathrm{v})$ agar (Bactoagar, Difco) were added to each tube of diluted serum. The mixtures were incubated at $37^{\circ} \mathrm{C}$ and colonial morphologies were determined after $24 \mathrm{~h}$. Cell-wall teichoic acid, protein A or CCFAS (crude, purified and partially degraded) were added to separate I $\mathrm{ml}$ portions of $\mathrm{I}: 8$ dilution of pooled human serum which contained one unit of CCFAS reactivity. The mixtures of serum and cell substances were incubated at $37^{\circ} \mathrm{C}$ for $2 \mathrm{~h}$, centrifuged at $1000 \mathrm{~g}$ for $2 \mathrm{~h}$, and then filtered through Millipore membrane filters (pore size $0.45 \mu \mathrm{m}$ ). A portion ( $0 . \mathrm{I} \mathrm{ml}$ ) of each filtrate was used in the SSA experiments to determine the effect of absorption with each of the three cell substances on the colonial morphologies of the test strains. Sera treated with saline only were used as controls. 
Assay of the serum reacting factor. The 'converting' activities (changing diffuse to compact type growth in SSA) of I4 different human sera were determined quantitatively using strain PS84 by the method of Yoshida (1973).

Effect of freezing and thawing on CCFAS. Normal human sera were frozen $\left(-40^{\circ} \mathrm{C}\right)$ and thawed $\left(37^{\circ} \mathrm{C}\right)$ Io times. After each thawing, the sera were tested for compact-colony formation using strain PS84 as described above.

Effect of treatment of fibrinogen with plasmin from human serum on CCFAS. Plasmin treatment of fibrinogen was performed by the method of Lipinski, Hawiger \& Jeljaszewicz (1967). Subsequent addition of thrombin did not cause coagulation, so it was assumed that all the fibrinogen was degraded by this treatment.

Quantitative determination of immunoglobulins in human sera. The $\operatorname{IgG}, \operatorname{IgA}$ and $\operatorname{IgM}$ contents of I 4 different human sera were determined by the immunoplate method (Behringwerke, Marburg-Lahn, West Germany).

\section{Immunological studies}

Preparation of hyperimmune rabbit anti-CCFAS serum. Purified CCFAS (Io mg) was dissolved in $0.1 \mathrm{ml}$ Tris buffer and combined with an equal volume of Freund's complete adjuvant (Difco). The antigen and adjuvant were mixed thoroughly and injected into the foot pads of two Australian rabbits (weighing approximately $2 \cdot 0 \mathrm{~kg}$ ) three times a week for one month. Rabbits were bled 7 days after the last injection.

Absorption of anti-CCFAS sera. Purified CCFAS $(5 \mathrm{mg})$ or lyophilized cells of strain PS84 grown in BHI medium with Tris buffer ( $\mathrm{IO} \mathrm{mg}$ ) were added to $\mathrm{I} \cdot 0 \mathrm{ml}$ rabbit antiCCFAS serum. The suspensions were incubated for $2 \mathrm{~h}$ at $37^{\circ} \mathrm{C}$ and then centrifuged to separate the serum from the complexed absorbent. Removal of antibody for CCFAS was confirmed by a haemagglutination test: sheep red cells $(\mathrm{I} \cdot 0 \mathrm{ml})$ were sensitized with $5.0 \mathrm{mg}$ purified CCFAS dissolved in Tris buffer, and then washed twice with the buffer; tests were performed with these sensitized cells using both absorbed and unabsorbed anti-CCFAS sera.

Agar diffusion test. Double diffusion in agar was performed using human serum and rabbit anti-human fibrinogen serum (Behringwerke).

\section{Evidence that CCFAS is distinct from protein A, teichoic acid and clumping factor}

Extraction of protein A. Crude protein A was obtained from strain PS84 by the method of Jensen (I959). Using DEAE-cellulose and Sephadex columns, a highly purified material was obtained by the method of Forsgren \& Sjöquist (1969). A 'protein substance' was extracted from strain wood 46 (a non-producer of protein A) by a similar procedure.

Determination of relative clumping factor reaction. The relative clumping factor reaction was determined with strain PS84 in limiting dilutions of human serum sufficient to cause clumping as described by Duthie (1955).

Extraction of wall teichoic acid. Fifty $\mathrm{ml} \mathrm{10} \%(\mathrm{w} / \mathrm{v})$ trichloroacetic acid was added to $\mathrm{Io} \mathrm{g}$ lyophilized cells of strain PS84. The mixture was maintained at $4{ }^{\circ} \mathrm{C}$ for $24 \mathrm{~h}$ with constant agitation using a magnetic stirrer, then centrifuged at $1000 \mathrm{~g}$ for $10 \mathrm{~min}$. The supernatant fluid was combined with 5 vols $95 \%(\mathrm{v} / \mathrm{v})$ ethanol, and kept at $4{ }^{\circ} \mathrm{C}$ overnight. The precipitate was recovered by centrifuging, washed once with $10 \mathrm{ml}$ of acetone/ether, and then vacuum dried. The teichoic acid was further purified according to the method of Matuno \& Slade (1970). 


\section{RESULTS}

Extraction and purification of CCFAS. On DEAE-cellulose chromatography, crude CCFAS yielded two fractions, one containing hexosamine and the other absorbing ultraviolet light at $260 \mathrm{~nm}$ (Fig. I). CCFAS, as determined by its ability to absorb the serum reacting factor, was found in the first peak only. When the fractions of the first peak were re-chromatographed on Sephadex G-200, a single peak, containing carbohydrate, was obtained (Fig. 2). However, when crude CCFAS was eluted from a DEAE-cellulose column with Tris buffer, $\mathrm{pH} 7^{\circ}$, four peaks, all characterized as carbohydrates by the presence of hexosamine, were obtained (Fig. 3): none of these was active.

Biochemical analysis of CCFAS. Purified CCFAS contained sugar, hexosamine, phosphorus and alanine in a molar ratio of $4 \cdot 0: I \cdot 0: 1 \cdot 2: 0 \cdot 2$. The total sugar content was $52 \%$ (w/w), composed of galactose, $N$-acetylglucosamine, ribitol and a trace of glucose, as determined by t.l.c. Gas-liquid chromatography indicated the presence of $32 \%(\mathrm{w} / \mathrm{w})$ galactose, I $\mathrm{I} \cdot 0 \%(\mathrm{w} / \mathrm{w})$ glucosamine and $\mathrm{I} \cdot 5 \%(\mathrm{w} / \mathrm{w})$ ribitol. Alanine, phenylalanine, glycine, serine, aspartic acid, valine and leucine were detected on amino-acid analysis: alanine showed the highest content, $0.29 \mu \mathrm{mol}$ (mg CCFAS) ${ }^{-1}$. Purified CCFAS showed higher proportions $(I \cdot 4, I \cdot 2, I \cdot 2$ and $I \cdot I$ times, respectively) of total sugar, hexosamine, ribitol and phosphorus than the crude preparation. The purified CCFAS produced a single precipitin line when diffused against normal human sera (see below). Its molecular weight was estimated as $5 \times 10^{4}$ daltons by the gel-filtration procedure.

Heat and $\mathrm{pH}$ stability of CCFAS. When CCFAS was heated at $105^{\circ} \mathrm{C}$ for $10 \mathrm{~min}$ at $\mathrm{pH}$ 8.4 , the absorbing ability of both crude and purified preparations for the serum reacting factor was not affected. The crude preparation remained stable even at $105^{\circ} \mathrm{C}$ for $30 \mathrm{~min}$. However the absorbing ability of each preparation was markedly decreased at $\mathrm{pH} 7.0$ and completely lost at $\mathrm{pH} 6 \cdot 0$.

Absorption of the serum reacting factor by various cellular products. The effects of adding, separately, various preparations of CCFAS (crude, purified and partially degraded) as well as protein A and teichoic acid to SSA inoculated with $S$. aureus PS84 are shown in Fig. 4. Only crude and purified CCFAS removed the serum reacting factor. Absorption of the serum reacting factor was also accomplished by CCFAS preparations from strain wood 46 (protein A negative) and from strain 32 (clumping factor negative).

Growth characteristics of $S$. aureus in fibrinogen soft agar. These experiments were designed to re-examine the findings of Alami \& Kelly (1959) and Forsum et al. (1972). Every compact type strain of $S$. aureus tested in SSA produced compact growth in normal soft agar containing at least $\mathrm{I} \cdot 25 \mathrm{~g}$ fibrinogen $\mathrm{I}^{-1}$ (see Fig. 5). This amount of fibrinogen is much less than the $4 \mathrm{~g}^{-1}$ found in normal human plasma. Fibrinogen, therefore, is active in compact-colony formation.

Agar diffusion test. The CCFAS produced a single precipitin line against normal human sera, and a reaction of identity was observed when normal human serum and rabbit antifibrinogen serum were diffused towards CCFAS suggesting that the active serum factor is fibrinogen degradation products.

Effect of freezing and thawing of human serum on compact-colony forming activity. Treated serum samples examined for compact-colony formation in SSA using strain PS84 were $50 \%$ less active after the first freezing and thawing cycle; and about $75 \%$ less active after the third cycle. Thereafter, the activity diminished no further up to the roth cycle.

Effect on compact colony formation of pretreatment of fibrinogen with plasmin from human sera. The addition of fibrinogen digested with plasmin to SSA inoculated with strain PS84 


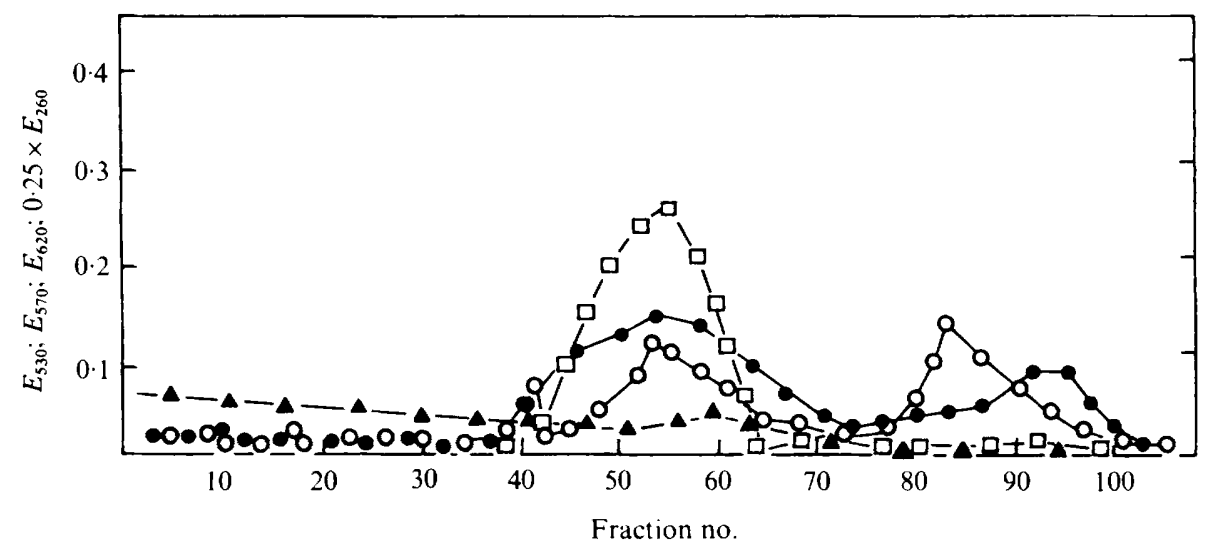

Fig. I. DEAE-cellulose chromatography of crude CCFAS extracted from $S$. aureus PS84: the column was eluted with Tris buffer $\mathrm{pH} 8.4$ and $5 \mathrm{ml}$ fractions were collected. $\square$, Hexosamine $\left(E_{530}\right) ; 0, E_{260} ; \bigcirc$, total sugar content $\left(E_{620}\right) ; \boldsymbol{\Delta}$, ninhydrin reaction $\left(E_{570}\right)$.

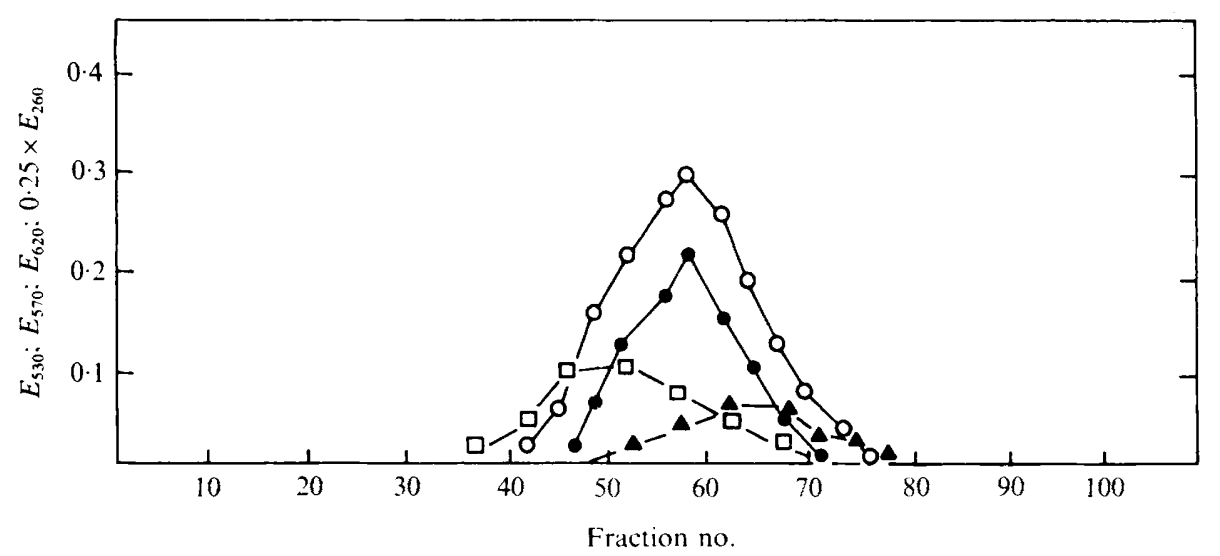

Fig. 2. Sephadex G-200 chromatography of partially purified CCFAS extracted from $S$. aureus PS84: the column was eluted with Tris buffer $\mathrm{pH} 8 \cdot 4$, and $5 \mathrm{ml}$ fractions were collected. Symbols as in Fig. $\mathbf{I}$.

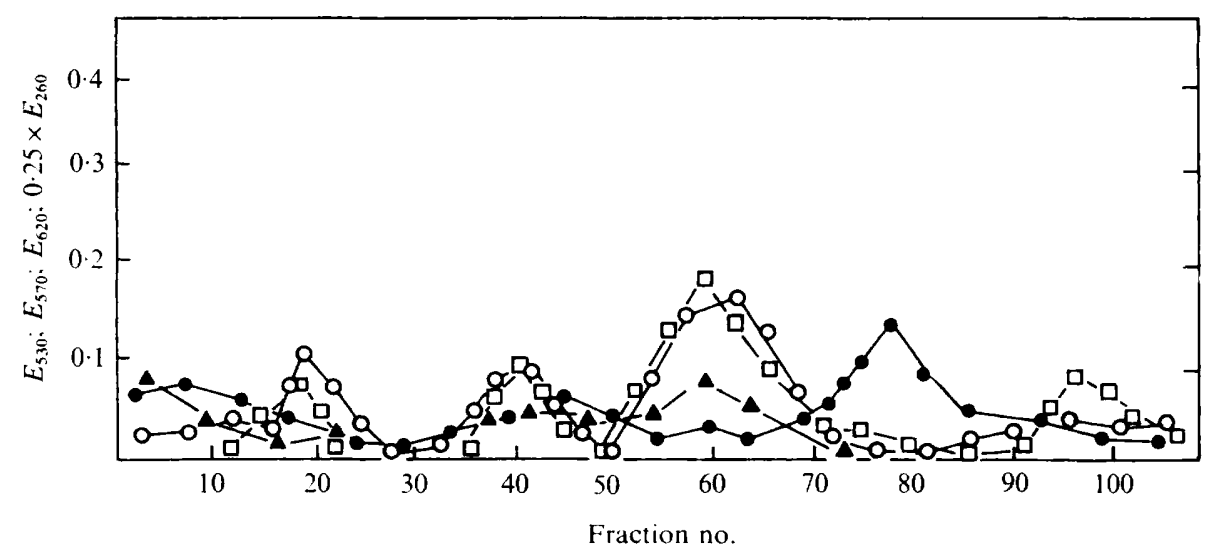

Fig. 3. DEAE-cellulose chromatography of crude CCFAS from $S$. aureus PS84: the column was eluted with Tris buffer $\mathrm{pH} 7.0$ and $5 \mathrm{ml}$ fractions were collected. Symbols as in Fig. I. 


$\begin{array}{cccccc}\begin{array}{c}\text { None } \\ \text { (control) }\end{array} & \begin{array}{c}\text { Crude } \\ \text { CCFAS }\end{array} & \begin{array}{c}\text { Purified } \\ \text { CCFAS }\end{array} & \begin{array}{c}\text { Partially } \\ \text { degraded } \\ \text { CCFAS }\end{array} & \text { Protein A } & \begin{array}{c}\text { Teichoic } \\ \text { acid }\end{array} \\ & & & & \end{array}$

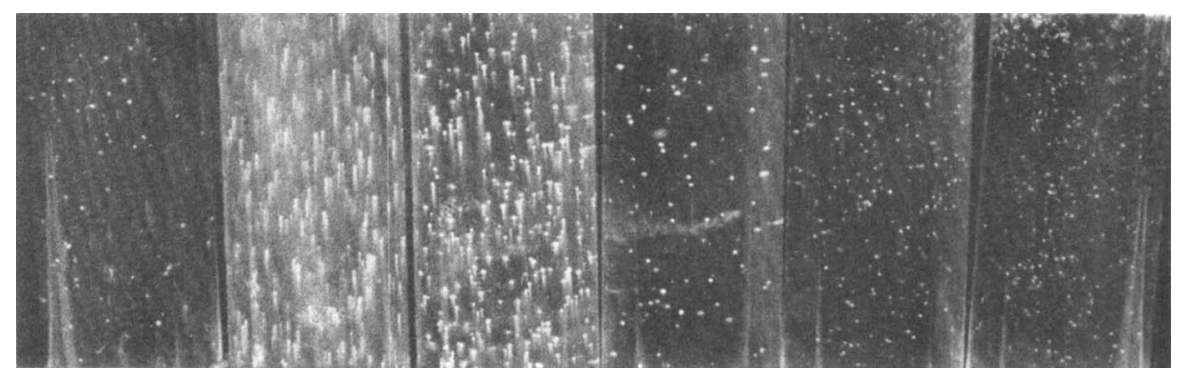

Fig. 4. Colonial morphologies of S. aureus Ps84 in serum soft agar in which the sera had been 'absorbed' with cellular products, as indicated.

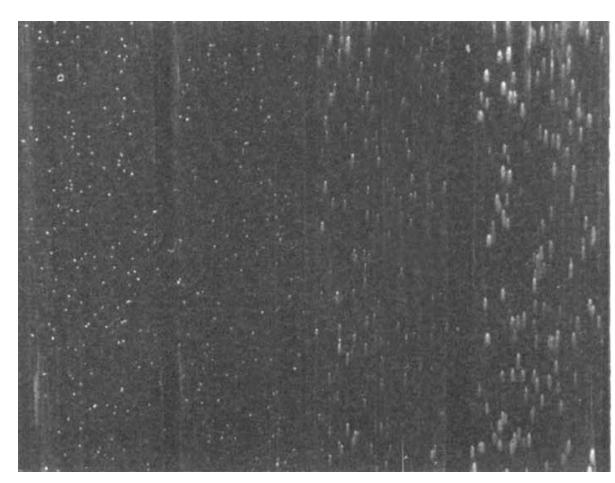

Fig. 5

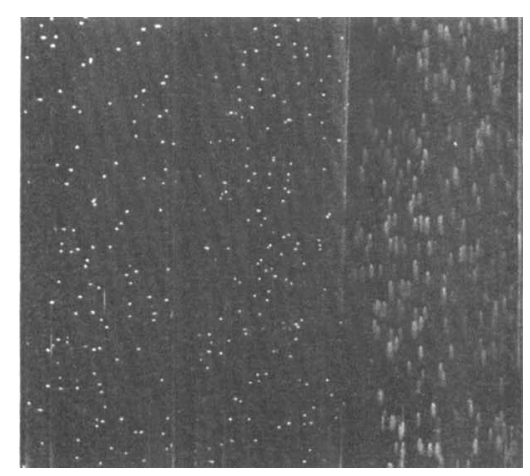

Fig. 6

Fig. 5. Colonial morphologies of $S$. aureus Ps84 in fibrinogen soft agar. Left to right, the tubes contain fibrinogen at $\left(\mathrm{g} \mathrm{l}^{-1}\right): 2 \cdot 5, \mathrm{I} \cdot 25,0 \cdot 6,0$.

Fig. 6. Colonial morphologies of S. aureus Ps84 in serum soft agar. Left to right, the tubes contain: added fibrinogen; added plasmin-digested fibrinogen; soft agar alone (control).

did not prevent compact-colony formation (Fig. 6). These results suggest that fibrinogen degradation products are active in compact-colony formation in SSA.

Effect of the immunoglobulin content of human sera on compact colony formation. Eighteen different human sera, all showing a $\mathrm{I}: 8$ or $\mathrm{I}: \mathrm{I} 6$ unit activity per $0 \cdot \mathrm{I} \mathrm{ml}$ CCFAS, as measured with strain PS84, were examined for their immunoglobulin contents. These contents (mg/ $100 \mathrm{ml}$ ) varied as follows: IgG from 4000 to 400 ; IgA from 500 to 100 ; and IgM from 600 to 100 (Fig. 7). Thus there is no linear relationship between immunoglobulin content and the reacting factor.

Serological differentiation between CCFAS and clumping factor. To determine whether CCFAS and clumping factor (Lipinski et al., 1967) were identical, experiments were done in which the $\mathrm{pH}$ value was either maintained at $\mathrm{pH} \mathrm{8.4}$ by buffering or allowed to change uncontrolled, and cultures were sampled at different stages of growth. Samples were tested for their ability to react both with rabbit anti-CCFAS antibody and in the clumping factor test. Under all conditions the clumping factor reaction was maximal in the early stage of growth, and then rapidly declined. Production of CCFAS at both alkaline and 


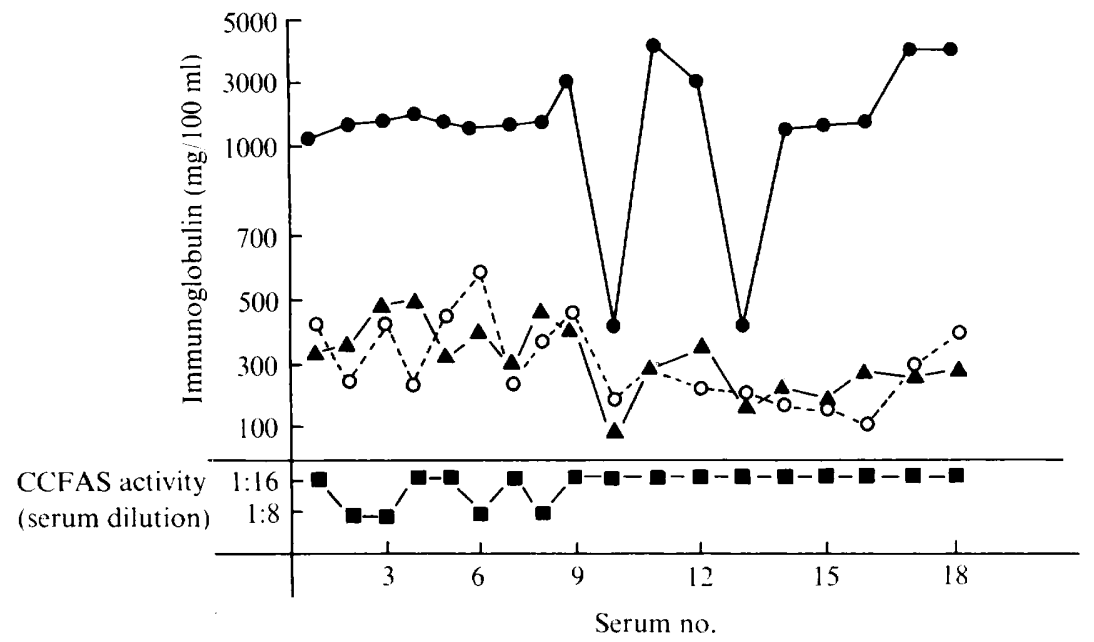

Fig. 7. Relationship between immunoglobulin content and compact-colony formation of various human sera tested with $S$. aureus $\mathrm{PS} 84 . \quad$, IgG; $\mathbf{\Delta}, \mathrm{IgA} ; \bigcirc, \mathrm{IgM} ; \mathbf{\square}, \mathrm{CCFAS}$ activity.

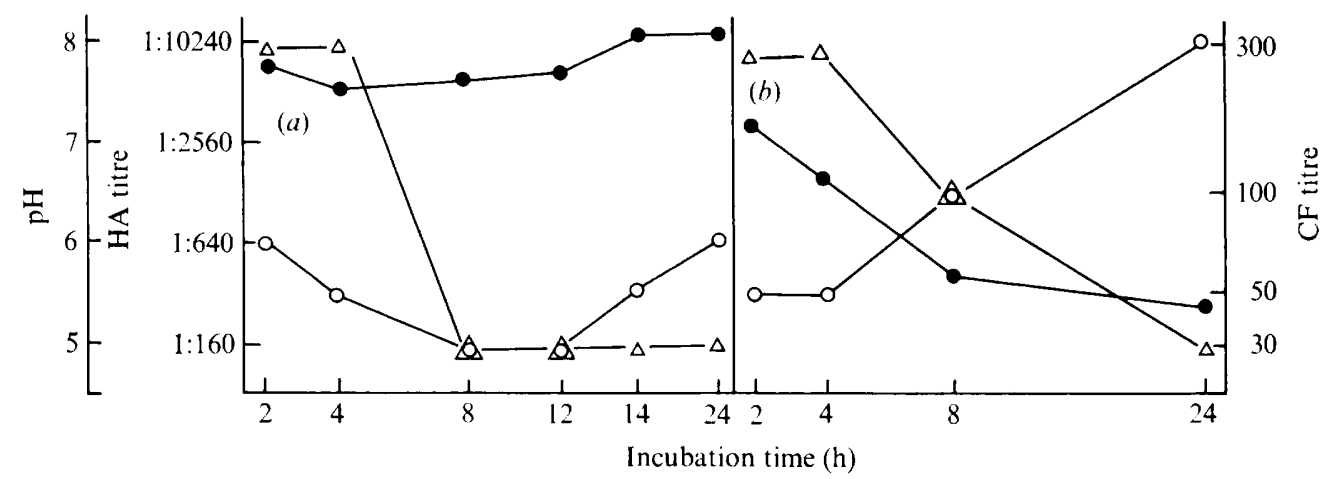

Fig. 8. Relationship between relative clumping factor reaction and absorbing activity for antiCCFAS antibody, and $\mathrm{pH}$ and growth phase of cultures of $S$. aureus $\mathrm{PS} 84 .(a)$ and $(b)$ show results for experiments at controlled alkaline $\mathrm{pH}$ and uncontrolled $\mathrm{pH}$ respectively. $\triangle$, titre of relative clumping factor reaction (CF titre); $\bigcirc$, titre of absorbing activity for anti-CCFAS antibody (HA titre); 9 , pH value.

uncontrolled pH did not correlate with that of clumping factor (Fig. 8). This suggests that CCFAS is probably distinct from clumping factor.

\section{DISCUSSION}

Forsum et al. (1972) attributed compact-colony formation of $S$. aureus to the reaction of protein A with the Fc fragment of IgG. This interpretation was challenged by Yoshida (1973) who showed that compact-colony formation was enhanced when the organism was incubated in SSA under alkaline conditions ( $\mathrm{pH} \mathrm{8.4)} \mathrm{whereas} \mathrm{the} \mathrm{reaction} \mathrm{reverted} \mathrm{to} \mathrm{diffuse}$ at $\mathrm{pH} 6 \cdot 0$ (Yoshida et al., 1974). No similar sensitivity to a change to acid $\mathrm{pH}$ has been demonstrated for the reaction of protein $\mathrm{A}$ with the $\mathrm{Fc}$ fragment of IgG. Therefore protein $\mathrm{A}$, more stable at acid $\mathrm{pH}$ than at alkaline, was unlikely to be responsible for the compactcolony phenomenon in SSA. More recently, Yoshida et al. (I975) reported a cell-surface 
associated polysaccharide capable of absorbing the compact-colony forming factor from serum, and they suggested that it, rather than protein $A$, was the staphylococcal factor responsible for compact-colony formation in SSA. Since this associated polysaccharide was composed of galactose, ribitol, $\mathrm{N}$-acetylglucosamine, alanine and a high amount of organic phosphorus, it was suggested that the CCFAS might be teichoic acid combined with galactose and an amino sugar. However, the human serum factor responsible for the compact-colony formation in SSA was not absorbed by a teichoic acid preparation extracted from cell walls. CCFAS did absorb the serum factor under alkaline conditions, but lost this property under even mildly acid conditions. Evidently, inactivation under acid conditions was caused by some part of the CCFAS polymer becoming dissociated. In contrast the activity of CCFAS was stable to heat.

Earlier, Alami \& Kelly (1959) had provided evidence that fibrinogen was the substance in plasma responsible for the compact-colony formation in SSA; this evidence was challenged by Forsum et al. (1972) on the grounds that the amount of fibrinogen necessary far exceeded the amount of fibrinogen in normal human plasma. In our re-examination, the effect of fibrinogen occurred at concentrations well below that found in normal human plasma. This paradox can be explained by the finding of Yoshida (1973) that the activity of CCFAS varies greatly from strain to strain. Furthermore, we did not detect any relationship between the amount of immunoglobulin (IgG or $\operatorname{IgM}$ ) and compact-colony formation in SSA. Direct evidence of fibrinogen involvement was provided by the agar diffusion line produced by the interaction of CCFAS with human serum. This line showed identity with the reaction line developed between normal human serum and rabbit anti-human fibrinogen serum. Evidence was also presented that fibrinogen degradation products were active.

Clumping factor activity (at alkaline $\mathrm{pH}$ ) varied greatly according to the stage of growth of the staphylococci, whereas the activity of CCFAS was unaffected by the age of the cells in our experiments, even under alkaline conditions. Our data also indicate that CCFAS is distinct from staphylocoagulase in that the coagulase contains about $35 \%$ protein (Siwecka \& Jeljaszewicz, (1968), whereas the CCFAS was free of protein and contained $53 \%$ total sugar and only a small amount of amino acids. A further distinction between staphylocoagulase and CCFAS is that active compact-colony formation is promoted by degradation products of fibrinogen; whereas, staphylocoagulase is active only with intact fibrinogen. The property of reacting with fibrinogen degradation products in addition to intact fibrinogen is a characteristic of clumping factor (Lipinski et al., 1967) as well as CCFAS, but the two substances differ in other respects as discussed above. That these two substances are distinct is strengthened by the fact that CCFAS is present in $S$. aureus strain 32, which is clumping factor negative. Furthermore, our experiments showed that the absorbing activity for anti-CCFAS antibody was not related to the relative clumping factor reactivity of staphylococci.

In conclusion our experiments indicate that CCFAS is distinct from clumping factor and staphylocoagulase, and confirm our earlier report that CCFAS was unrelated to staphylococcal protein A (Yoshida et al., I975). Therefore, CCFAS can be regarded as the third staphylococcal substance shown to react with fibrinogen.

We are indebted to Dr Morris Tager, Department of Microbiology, Emory University, Atlanta, Georgia, U.S.A., Dr Jay O. Cohen, Center for Disease Control, Atlanta, Georgia, U.S.A., and Dr Charles L. San Clemente, Department of Microbiology and Public Health, Michigan State University, East Lansing, Michigan, U.S.A., for their suggestions and critical evaluation of the original manuscript. 


\section{REFERENCES}

Alami, S. Y. \& Kelly, F. C. (I959). Demonstration of staphylococcal clumping factor and free coagulase in soft agar media. Journal of Bacteriology $\mathbf{5 8}, 539-544$.

DuTHIE, E. S. (I 955). The action of fibrinogen on certain pathogenic cocci. Journal of General Microbiology I3, $383-436$.

Elson, L. A. \& Morgan, W. T. J. (I953). A colormetric method for the determination of glucosamine and chondrosamine. Biochemical Journal 27, I828-1829.

Finkelstein, R. A. \& Sulkin, S. E. (1958). Characteristics of coagulase negative and coagulase positive staphylococci in serum-soft agar. Journal of Bacteriology 75, 339-344.

Forsgren, A. \& SJöQuist, I. (1969). Protein A from Staphylococcus aureus. VII. Physicochemical and immunological characterization. Acta pathologica et microbiologica Scandinavica 27, 466-48 I

Forsum, U., Forsaren, A. \& HJelm, E. (1972). Role of protein A in the serum-soft agar technique. Infection and Immunity 6, 583-586.

IwATA, K. \& EDA, T. (1968). Studies on unique staphylococcal strains exhibiting high virulence for mice by intraperitoneal inoculation. I. Morphological and biological properties of the strains. Japanese Journal of Bacteriology 23, I65-17 I.

JENSEN, K. (I959). Undersölgelser over staphylococcernes antigenstruktur. Thesis. Copenhagen: Munkgaard.

Lipinski, B., Hawiger, J. \& Jeljaszewicz, J. (I967). Staphylococcal clumping factor with soluble fibrin monomer complex. Journal of Experimental Medicine 126, 979-988.

Matuno, T. \& Slade, H. D. (I970). Composition and properties of a group A streptococcal teichoic acid. Journal of Bacteriology ro2, 747-752.

Morris, D. L. (I948). Quantitative determination of carbohydrates with Dreywood's anthrone reagent. Science 107, 234-255.

Siwecka, M. \& Jeljaszewicz, J. (1968). Purification and some properties of staphylococcal coagulase. Experimental Medicine and Microbiology 20, $125^{-1} 37$.

SpIro, R. G. (I959). Studies on the biosynthesis of glucosamine in the intact rat. Journal of Biological Chemistry 234, 742-748.

Trevelyan, W. E., Procter, D. P. \& Harrison, J. S. (I950). Detection of sugar on paper chromatograms. Nature, London 166, 444-445.

Yoshida, K. (I973). Compact-colony forming activity and the effect of pH on compact-type growth of Staphylococcus aureus strain in serum-soft agar. American Journal of Clinical Pathology 59, 41 2-4I 6.

Yoshida, K., SMITH, M. R. \& NAITo, Y. (1970). Biological and immunological properties of encapsulated strains of Staphyloccus aureus from human sources. Infection and Immunity 2, 582-532.

Yoshida, K., Nakamura, A., OHтомo, T. \& Iwami, S. ( I 974). Detection of capsular antigen production in unencapsulated strains of Staphylococcus aureus. Infection and Immunity 9, 620-623.

Yoshida, K., Онтомо, T. \& MineGishi, Y. (I975). Compact-colony forming active substance extracted from Staphylococcus aureus. Japanese Journal of Microbiology 19, 75-76. 